\title{
ON SUBMARINE SLUMPING IN THE LOWER LUDLOW ROCKS OF NORTH WALES
}

SIR,-A recent paper by Professor Boswell 1 raises several points of interest. Some of these relate to the mode of origin of certain highly disturbed sheets of sediment, intercalated among normal sediments; others are concerned with the technique of geological mapping. Only those matters which refer to the mode of origin of the disturbed rocks are dealt with here.

Professor Boswell alleges that there is "no indisputable evidence" that these disturbances are due to subaqueous sliding ("slumping"). It is not quite clear whether he disbelieves that they are subaqueous or are due to sliding, or both.

The evidence in favour of these disturbed masses, or slumps as I called them, being subaqueous and due to sliding is as conclusive as any geological evidence can be: It has been stated before (Quart. Journ. Geol. Soc., Xcv, 1940 , p. 381) but apparently it needs to be repeated.

Anyone who closely examines these disturbed masses in clear sections which show their relation to the normal sediments above and below them will observe that

(a) They rest with a fairly sharp boundary on undisturbed shales or mudstones.

(b) They contain pieces of various shapes and sizes of mudstones somewhat similar to those below and retaining obvious traces of stratification, but these pieces lie at all angles, sometimes much crumpled and detached from one another.

(c) In appropriate sections they are overlain by normal sediments similar in kind to those that underlie them.

(d) At the base of the overlying normal sediments there is a graded bed which passes upward in a few inches into the overlying sediments and obviously forms the base of that group of sediments.

(e) The graded bed adheres closely to the top of the disturbed bed, and in many cases pieces can be knocked off at the contact which include both the disturbed beds below and the graded bed above. The contact is relatively even, though there may be some small irregularities on it, and it is certain that there has been no sliding between the graded bed and the disturbed beds below since the strata were formed. The contact is therefore an original undisturbed contact ; I gave a list (op. cit., pp. 375, 6) of 39 such contacts in Denbighshire, and I have no doubt that many more could be found.

From these facts certain conclusions follow inevitably:

(1) The disturbed beds were emplaced after the underlying mudstones were deposited; this is indeed self-evident.

(2) The overlying beds, including the graded part at their base, were laid down after the disturbed bed on which they rest had been emplaced. This conclusion is made inevitable by the fact that there has been no sliding at the contact between the base of the overlying mudstones and the disturbed beds.

It has been suggested as an explanation of some disturbed beds that they have acquired their structures as a result of being, as it were, extruded like tooth-paste from between the overlying and underlying sediments some time after these normal sediments were laid down, and in consequence of a great load of overlying sediments. It must be presumed also that there was some freedom of movement for the extrusion. The undisturbed and unmoved upper contacts of the North Wales slumps rule out this alternative explanation absolutely.

There appears, however, to be a vague idea that the whole of a disturbed bed from top to bottom can be interpreted as the slide along which the material is extruded. If such an idea prevails it is disposed of by the fact

1 The alleged subaqueous sliding of large sheets of sediment in the Silurian rocks of North Wales. Liverpool and Manchester Geol. Journ., 1, Pt. 2 (1952), 1953, 148-152. 
that the origin of the slump and of the graded bed which overlies it have something in common. Their close association suggests that the sliding of a mass of sediments caused the water to become muddy and that shortly afterwards the cloud of sediment settled on the slump. Or an earthquake set the muds moving and also disturbed the sediments on the sea floor. In the only case, however, where the point of origin of a slump has been described, the graded bed occurs only over the slump and does not extend on to the sea floor above its point of origin.

It is clear, therefore, that a given slump bed was formed at a time between the deposition of the underlying sediments and that of the overlying sediments; in this sense the slumps are contemporaneous with sedimentation. Further, since both the overlying and underlying sediments are admitted to be of marine origin, it would be surprising if the slumps are not also of that origin. That they are subaqueous is proved by the deposition upon them of the graded bed forming the base of the overlying sediments; it is also evident that the top of the slump was the actual floor of the sea when the sedimentary grains of the graded bed began to shower down upon it.

Examination of a slump will usually reveal that pieces of included sediments lie in it at all angles, and not uncommonly overturned or even recumbent folds have been truncated at the base of the graded bed. The slump beds have therefore acquired their structures before the overlying beds were laid down upon them.

It would be of great interest if anyone can suggest any way of producing these manifold structures in muds on the sea floor except by sliding.

The Sedgwick Museum,

O. T. JONES. CAMBRIDGE.

6th March, 1953.

\section{ACCURACY IN GEOLOGICAL LOCALITIES}

Str,--In this Magazine (Ixxxix, 152) A. M. Davies sets right Cossman's view by saying that the interesting Miocene gastropod Pereiraia gervaisi is found in Slovenia and not in Ukraina. Ivandel or correctly Ivandol $\left(45^{\circ} 48^{\prime} 48^{\prime \prime}, 15^{\circ} 19^{\prime} 20^{\prime \prime}\right.$ E. Greenwich), however, should not be retained in the geological literature, as the locality of the gastropod, for the valley (one mile long and without settlements) is little known even in Slovenia. There are some more localities where this gastropod has been found, as for instance: Stara vas, Zgornje Vrhpolje, Ṡmarje, Orehovica, Cerov log, all of them together with Ivandol are near St. Jernej. In Slovene geological literature St. Jernej is indicated as the locality for this gastropod, and it would seem more appropriate to use it in the foreign literature, too.

Inst, of Geol. and Paleont., UNIVERSITY OF LJUBLJANA.

Anton Ramovšs. 15th March, 1953.

\section{GRAVITY MEASUREMENTS OVER THE NORTHERN PENNINES}

SIR,-The announcement by J. Hospers and P. L. Willmore of the discovery of a closed area of negative Bouguer anomalies in and around Upper Weardale and the preliminary account of more detailed work by M. H. P. Bott and D. Masson-Smith (Geol. Mag., xc, 117-126, and 127-130) are both most welcome. There will, I am sure, be general agreement with the authors that the field of negative anomalies is probably the expression of the existence of a buried granite mass. But not everyone will so readily agree with the next step taken by the authors, namely that the "Weardale granite "-assuming it to be real-was the source of the mineralization of the area. Taking this step precludes the possibility that the "granite" may be pre-Carboniferous, 